\title{
Learning Human Anatomy Using Three-Dimensional Models Made from Real-Scale Bone Pieces: Experience with the Knee Joint among Pre-Service Biology Teachers
}

\author{
Aprendizaje de la Anatomía Humana Utilizando Modelos Tridimensionales a Escala: \\ Experiencia con la Articulación de Rodilla en Profesores de Biología en Formación
}

Pablo A. Lizana*; Cristian Merino*; Arlette Bassaber ${ }^{* * * *}$; Ricardo Henríquez*; Vega-Fernández, G." \& Octavio Binvignat"****

LIZANA, P. A.; MERINO, C.; BASSABER, A.; HENRÍQUEZ, R.; VEGA-FERNÁNDEZ, G. \& BINVIGNAT, O. Learning human anatomy using three-dimensional models made from real-scale bone pieces: experience with the knee joint among pre-service biology teachers. Int. J. Morphol., 33(4):1299-1306, 2015.

SUMMARY: This study aims to assess the efficiency of using real-scale knee models to learn about the locomotor system. Participants included a total of thirty-nine second year students in a Human Anatomy class of a Biology Teaching course. One week before the intervention, a pre-test was administered to assess the students' prior knowledge. The pre-service biology teachers were provided with a real-scale plaster model of a knee bone and were subsequently required to identify and create their own model of bone, joint and muscle elements. At the end of the intervention, a post-test was performed and opinion survey, in addition to a comparison with other locomotor system structures (four images: knee joint, muscular component of lower limb, shoulder joint and pelvic bone). Students' scores increased significantly in relation to the pre-test, both among the total sample $(\mathrm{P}=0.000)$ and between sub-groups divided according to participant gender (male $\mathrm{P}=0.0021$; female $\mathrm{P}=0.0005)$ as well as compared to other structures $(\mathrm{P}<0.05)$. Furthermore, the pre-service biology teachers showed significant increases in their scores on a Likert-type opinion survey, indicating that these types of interventions promote their motivation for the course (89.2\%) as well as their learning $(97.8 \%)$ and would be advisable for future students $(95.5 \%)$. The results show that the use of real-scale models and associated work fosters student motivation and enhances the learning of human anatomy.

KEY WORDS: Anatomical science; Education; Gross anatomy; Human body; Pre-service biology teachers.

\section{INTRODUCTION}

In recent decades, the study of disciplines comprising the morphological sciences - anatomy, neuroanatomy, embryology and histology - has experienced significant changes around the world, such as reductions in the number credits and teaching hours (Drake et al., 2002; Inzunza, 2003; Inzunza et al., 2007, 2008).

In some schools in Chile, a remarkable increase in the number of students per class has led to a disturbing teacher/student relationship, in addition to significant reductions in access to cadaveric material (Inzunza, 2003), quite a paradoxical aspect in the anatomical disciplines. Meanwhile, new advances in human anatomy, such as imaging diagnosis technologies and conservation forms (von Hagens, 1979; Latorre et al., 2007), are trying to fill the gaps left by the problems outlined above; however, these require basic science and health students to possess increased knowledge and expertise.

The teaching of anatomy is usually structured around 'scientific models', which serve as the 'backbone' (structuring axis) organizing teaching aims, content and assessment criteria. It is deemed important that students learn models and, at the same time, learn how to use them and develop creative skills in order to reconstruct them (Oliva et al., 2007). For the purpose of this paper, models can be regarded as the basic units of scientific reasoning, allowing scientists to understand the situations that they are investigating, and sometimes even permitting them to be ahead of the facts by formally manipulating the models to determine their assumed or expected behaviors without needing to resort to actual experiments (Nersessian, 1995, 2008).

Laboratory of Morphological Sciences, Institute of Biology, Pontificia Universidad Católica de Valparaíso, Valparaiso, Chile.

** Laboratory of Chemistry Education, Institute of Chemistry, Pontificia Universidad Católica de Valparaíso, Valparaíso, Chile.

**** Colegio Sagrados Corazones Monjas Francesas, Viña del Mar, Chile.

**** Faculdade Mineirense FAMA, Faculdade de Medicine, Mineiro-GO, Brasil. 
LIZANA, P. A.; MERINO, C.; BASSABER, A.; HENRÍQUEZ, R.; VEGA-FERNÁNDEZ, G. \& BINVIGNAT, O. Learning human anatomy using three-dimensional models made from real-scale bone pieces: experience with the knee joint among pre-service biology teachers. Int. J. Morphol., 33(4): 1299-1306, 2015.

In any case, the didactic (i.e., instructional) context makes it impossible to teach scientific models in their 'purest' forms; as with any type of scientific knowledge, models need to be adapted, restructured and presented in different formats in accordance with the intended audiences (IzquierdoAymerich \& Aduriz-Bravo, 2003). Modeling activities comprise complex processes whose development requires a variety of skills, in addition to domain-specific content knowledge and a number of distinct epistemological commitments (Justi \& Gilbert, 2001). This implies that students must not only be taught some models, but the previously mentioned elements must also be fostered so that they obtain the necessary skills to apply and assess models, or even reconstruct them. In the contemporary philosophy of science, there is still a debate regarding the meaning and use of the term 'model'; nevertheless, there is reasonable consensus that models constitute 'substitutes' or 'surrogates' of the real systems under inspection, which are too complex to be understood in their totality. Thus, scientists work with 'representations' of those systems that retain only the essential aspects that are deemed important (Adúriz-Bravo, 2013). This is why models work as 'facilitators' for the comprehension of the real world (Gilbert et al., 1998a, 1998b).

Important advances in teaching and learning are described for the study of the locomotor system, including cadaveric preparations (Inzunza, 2003), virtual aspects such as websites with animated images (Bravo \& Inzunza, 1995; Inzunza, 2003), anatomy webpages (Inzunza \& Bravo, 2002), three-dimensional virtual models (Van Sint Jan et al., 2003; Wang et al., 2006; Codd \& Choudhury, 2011), muscle clay modeling (Motoike et al., 2009; Haspel et al., 2014), clay organ cross-sections (Oh et al., 2009), and body painting (Op Den Akker et al., 2002; McMenamin, 2008; Finn \& McLachlan, 2010).

It has been observed that visual clues are important in the learning of human anatomy (Lufler et al., 2012; Vorstenbosch et al., 2013), especially when integrated into theoretical, practical and virtual environments (Bravo \& Inzunza, 1995; Lizana et al., 2010) to promote more active learning (Drake et al., 2009). The formation of mental images of complex anatomical structures by students remains a difficult task (Sugand et al., 2010). However, work in and experience with anatomy helps in the development of spatial skills (Fernandez et al., 2011; Vorstenbosch et al.), as does working with models representing the structure and functioning of upper limb segments (Cloud et al.), the pelvis (Khot et al., 2013), or the complicated veterinary anatomy of the equine foot (Preece et al., 2013).

Classic educational curricula involving anatomy have aimed toward two-dimensional (2-D) cross-section studies
(Nolte \& Angevine, 2007). These techniques were suitable when sufficient time was provided to internalize and transform this information into three-dimensional (3-D) (Drake et al., 2002; Inzunza; Inzunza et al., 2007, 2008). Therefore, the success of this activity generally depends on the innate spatial abilities of students (Rochford, 1985; Guillot et al., 2007; Hegarty et al., 2009) and/or their previous knowledge of mental rotation tasks (Hoyek et al., 2009). Although new technology-based educational tools, such as computer graphics and virtual reality programs, allow for 3-D representations of the brain, these activities have the potential to increase the cognitive workload and aid in the development of students with weak spatial skills (Garg et al., 1999; Huk, 2006; Levinson et al., 2007). While computer-aided learning can be extremely valuable in many situations, such tools are limited by their inability to be tangibly manipulated. This characteristic may be critical for success with 3-D learning.

When students themselves build three-dimensional models, they have the opportunity to learn and strengthen their work in human anatomy because they are working with materials constructed by themselves or their peers and teachers. This will give them the chance to strengthen their technical skills, develop and innovate anatomical techniques directly related to the learning of human anatomy and obtain practical skills that will be of great help when they are teaching in schools.

The development of such three-dimensional products using the scientific method, and therefore relating to research in this field, is being promoted. This is especially important in the training of biology teachers, who, in addition to internalizing the essentials of human anatomy, will have to pass this information to their future students. Interventions in the teaching of anatomy such as working with 3-D models are currently being used in medical schools in subjects as complex as neuroanatomy (Estevez et al., 2010), which supports the idea that such learning can be effective during the early stages of biology teacher training. The hypothesis of this work is that there is a positive relationship between the use of 3-D models and a real-scale bone base in the study of the locomotor system, leading to improvements in student assessment performance and motivation.

\section{MATERIAL AND METHOD}

Participants. The study was conducted in the Human Anatomy class of a second year pre-service biology teacher course during the second term of 2012 (August to December), at the Curauma Site of the Pontificia Universi- 
dad Católica de Valparaíso, Chile. The course was structured based on systemic anatomy, and the first unit, covered during the first six weeks of the semester, involved the locomotor system.

The class included 39 pre-service biology teachers and one of the inclusion criteria required them to attend all of the evaluation sessions. The second stage of the survey was anonymous.

Model Construction Activity. Students were given a realscale model bone component of a human knee, which includes the following structures: distal femoral epiphysis, proximal tibial epiphysis, fibula and patella (see Fig. 1A). The models were made using silicone molds (specifically, PlastiquímicaTM, a component made out of a base and midviscosity catalyzer; the mixture of these two components must be in a proportion of 20:1 and they were dried at room temperature), using real bones as molds (Usta et al., 1996).

A model of the bone components of the knee joint was provided to groups of two to three students. Based on this model, the students were asked to create their own models of the distinctive elements of the knee joint (ligaments, muscle origin and insertion and menisci). The students were given two weeks to complete this activity.

Tests. A pre-test was administered to determine a baseline for the class (before model construction). A post-test was subsequently administered to assess whether learning had increased as a result of the construction of the 3-D model of the knee. The pre- and post-tests consisted of four images: (1) anterior view of knee joint (see Fig. 2A), (2) posterior view of the surface muscular component of the lower limb, (3) anterior view of the shoulder joint, and (4) side view of the pelvic bone.
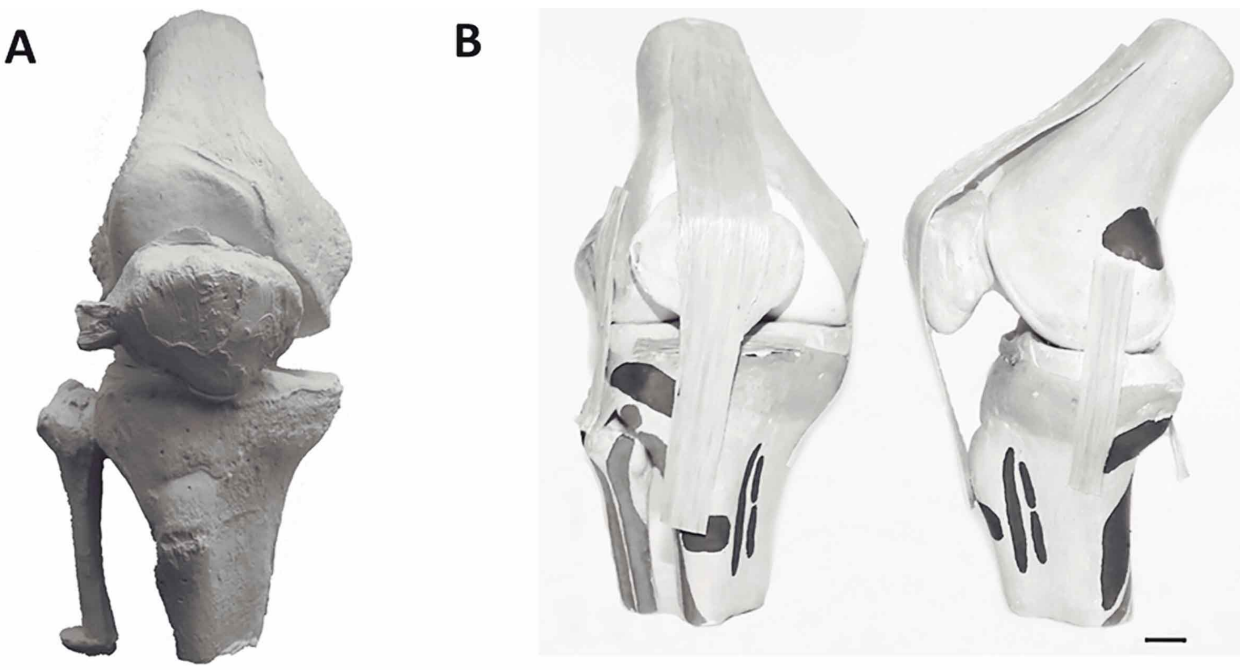

Opinion Survey. After completing the three-dimensional anatomical model activity, an opinion survey including four questions (rated on a Likert-type scale) was administered. The survey was completely anonymous and referred to motivation, whether models support learning, material design and whether the methodology would be recommended for future generations. The ratings included four categories: (1) totally agree, (2) agree, (3) disagree and (4) strongly disagree.

Focus Group. At the end of the academic semester (December 2012), students in the 1st through 4th years of the Biology and Pre-service Teacher training program were interviewed. Two interviews were conducted with different focus groups: one with 5 students from the first through third years and another with 6 students from the third through fifth years. The survey was conducted by an independent agent, in this case a psychologist. Students were asked about teaching and learning experiences they found to be successful in their learning.

Statistical Analysis. The discrete variables of the study were pre-service biology teachers and the numbers of students who responded to each of the questions, reported in terms of frequency (n) and percentage (\%). Continuous variables are presented as the mean \pm the standard deviation $( \pm \mathrm{SD})$; assessments were reported as the qualification $(\%) \pm$ the standard deviation $( \pm \mathrm{SD})$.

Assessment scores in competitions, course grades, and age were examined using parametric (t-test) and nonparametric analysis (Wilcoxon matched pairs). Differences in pre- and post-test scores were determined using nonparametric tests (Wilcoxon matched pairs) and the tests comparing the knee with other structures were examined using Students' t-tests for related samples. Statistical analysis
Fig. 1. 3-D Models done by students of the human anatomy lecture for Pre-Service Biology Teachers. Locomotor system unit. Integration knee osteoartromuscular model (A) rustic model provided to students, (B) final result of the knee model made by students (left, anterior view; right lateral view). Scale bar indicate 1 $\mathrm{cm}$. 


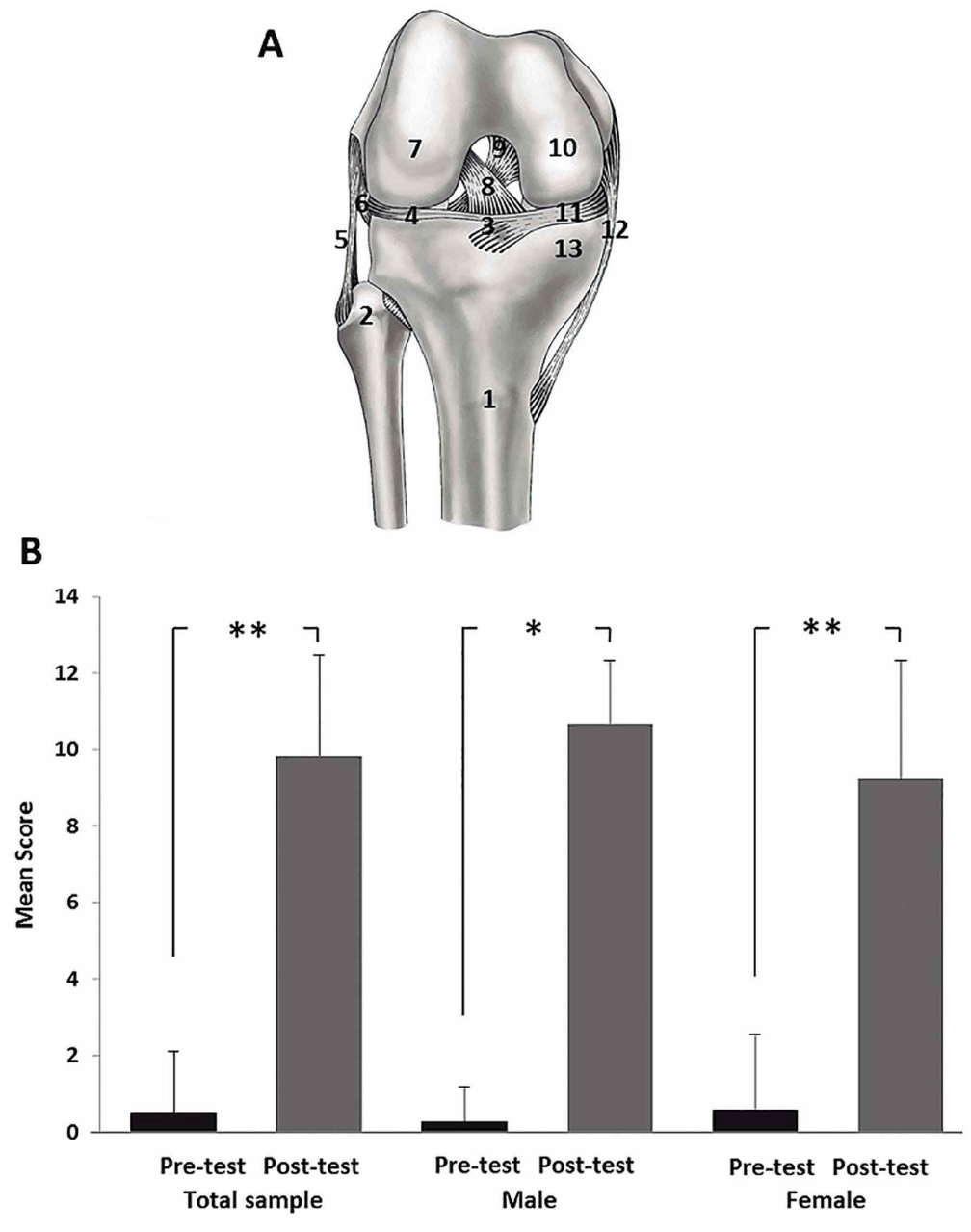

$\mathrm{p}=0.0021$; female $\mathrm{p}=0.0005$; see Fig. 2B). On the test on identifying knee articulation structures in comparison to other structures of the locomotor system, there were significantly higher scores for the knee articulation figure (see Fig. 3).

The results from the survey, which asked students to evaluate their appreciation of this teaching-learning method on a Likert-type scale, indicate complete acceptance ranging between $79 \%$ and $98 \%$ (Table I). No students answered "totally disagree" and only one student marked "disagree" for the first question. Because the survey was administered only once, it was answered by 34 students (15 male).

In relation to the focus group, when asked for successful experiences that have significantly influenced their learning, students repeatedly mentioned the construction of anatomic models. Related opinions include the following:

1. "I find the mo2dels very didactic; making teaches you a lot, the practical things" (3rd-year student);

2. "The opportunity to execute things by yourself, learning terminology, searching for references on our own, that leads to tremendous learning" (2nd-year student);

3. "Group learning is also promoted; you are able to learn much more that way" (3rd-year student).

Fig. 2. Human knee pre-test and post-test. (A) Figure used in the tests. (B) Test results for gender, $* \mathrm{P}<0.005$, $* * \mathrm{P}<0.0001$.

was performed using version 12.1 of the STATA statistical package for Windows XP (Microsoft Corp., Redmond, WA). A value of $p<0.05$ was considered significant.

\section{RESULTS}

Out of the 39 students in the class, 29 (17 male) completed the two tests (pre- and post-tests, test on knee articulation versus other structures from the locomotor system). Students who were absent for one of the tests were excluded so that the progress of each student could be evaluated. Significant differences were identified between the pre- and post-test scores, $\mathrm{p}=0.0000$.

When assessing the results in terms of student gender, there were also statistically significant increases (male

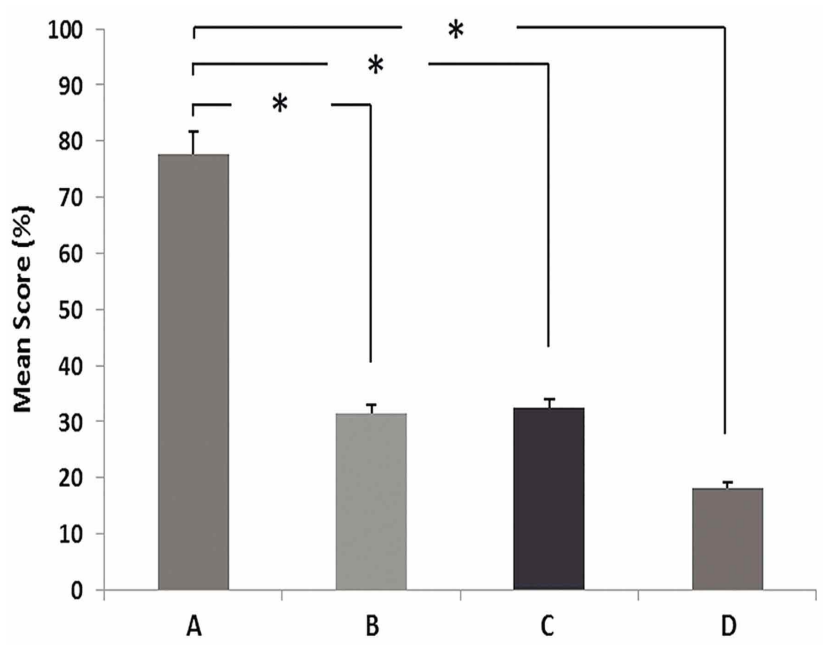

Fig. 3. Results for the structure identification test in locomotor system segments for gender and total sample. (A) anterior view of knee joint (B) posterior view of the muscular surface component of the lower limb, (C) anterior view of the shoulder with bone and ligaments components, and (D) lateral view of the coxal bone. 
LIZANA, P. A.; MERINO, C.; BASSABER, A.; HENRÍQUEZ, R.; VEGA-FERNÁNDEZ, G. \& BINVIGNAT, O. Learning human anatomy using three-dimensional models made from real-scale bone pieces: experience with the knee joint among pre-service biology teachers. Int. J. Morphol., 33(4):1299-1306, 2015.

Table I. Survey results from students about their appreciation of this teaching-learning method.

\begin{tabular}{|c|c|c|c|c|}
\hline Statements & 1 & 2 & 3 & 4 \\
\hline $\begin{array}{l}\text { A. The learning methodology (models) has increased my } \\
\text { motivation for the lectures. }\end{array}$ & --- & $\begin{array}{c}1 \\
(1.5)\end{array}$ & $\begin{array}{c}4 \\
(9.2)\end{array}$ & $\begin{array}{c}29 \\
(89.2)\end{array}$ \\
\hline $\begin{array}{l}\text { B. The learning activities in which models were used have } \\
\text { helped me to leam the contents approached in classes. }\end{array}$ & --- & --- & $\begin{array}{c}1 \\
(2.2)\end{array}$ & $\begin{array}{c}33 \\
(97.8)\end{array}$ \\
\hline $\begin{array}{l}\text { C. The material used in the course (model) is well designed, as } \\
\text { it resembles reality. }\end{array}$ & --- & --- & $\begin{array}{c}9 \\
(21.3)\end{array}$ & $\begin{array}{c}25 \\
(78.7)\end{array}$ \\
\hline $\begin{array}{l}\text { D. Ir ecommend this teaching methodology in other future } \\
\text { anatomy lectures. }\end{array}$ & --- & --- & $\begin{array}{c}2 \\
(4.5)\end{array}$ & $\begin{array}{c}32 \\
(95.5)\end{array}$ \\
\hline
\end{tabular}

$1=$ Totally disagree; $2=$ Disagree; $3=$ Agree; $4=$ Totally agree. Values in frequency and $(\%)$.

\section{DISCUSSION}

In this study, we assessed the effectiveness of an activity designed to teach human anatomy of the locomotor system to second-year students in the Biology and Preservice Teacher training program, using a 3-D real-scale base model for the construction and location of ligament, muscle and stabilization (meniscus) structures in a human knee joint. Significantly improved performance was observed through pre- and post-test evaluations, as well as a test comparing the elements included in the model with other structures of the locomotor system.

The results of this study are similar to those reported by Estevez et al., who used a ventricular system base model for the construction of periventricular structures. Their results indicate that this type of activity is recommended for all students, regardless of their learning styles. This work supports the hypothesis that there is a direct relationship between the construction of a physical model and the internal development of 3-D structures.

3-D models promote anatomical learning, generating an effective bridge between 2-D structures and 3-D understanding of human anatomy. In addition, it has been observed that students working on tasks that require the understanding of 3-D spatial relationships have a significant advantage over those who have not completed such activities (Estevez et al.).

This study emphasizes the use of real-size models that accurately represent bone structures as educational resources. In this regard, we agree with Villarroel Guerra \& Medina Otazo (2011), who reproduced bones of the skull that are difficult to obtain, such as palatine, nasal and sphenoid bones, arguing that such strategies represent an excellent teaching tool, as suggested by Segovia Geraldo \& Moreno Monje (1989) in the reproduction of plaster and paraffin anatomical pieces. In this sense, 3-D printing is new recourse in the teaching of human anatomy because it would provide students with anatomical pieces that are nearly identical to real structures to enhance their development and learning (Vaccarezzza \& Papa, 2015).

The difficulty of using rustic anatomical models (see Fig. 1A) is for students to determine, from the very beginning, which features of models represent real anatomical structures and which reflect the defects of the mold (see Fig. 1A-B). Therefore, students should investigate various sources of information to differentiate between the corresponding structures. This is evident in the second comment of the focus group.

The present study suggests that pre-service biology teachers can achieve a better understanding of 2-D images by means of active learning activities involving working with 3 -D real-scale anatomic models, as indicated by their significantly higher results on 2-D tests.

Although students start with a model that has the same dimensions and anatomical features of a real bone structure, they end up with a model that differs from an actual knee with regard to the dimensions of ligaments and menisci, among other differences. However, the results show that this type of intervention supports the learning of anatomy through a simplified model of anatomic regions; it also reduces cognitive overload, increases enthusiasm in student participation and helps students solve spatial problems related to anatomical structures (Chan \& Cheng, 2011), as well as encouraging active learning in students (Drake et al.; Estevez et al.).

Future investigations should incorporate evaluations that are in 3-D or have greater spatial complexity because differences in working with 3-D models can be visualized in this type of task, as stated by Estevez et al., in the area of 
neuroanatomy. In addition, it is important to include the effects of the students' innate abilities in spatial assignments (Guillot et al.; Hegarty et al.; Khot et al.) given that generic differences have been observed between men and women in which men obtain higher scores in mental rotation tasks (Masters \& Sanders, 1993).

Another important consideration is that such models are inexpensive compared to commercial models, a fact that is also reviewed by Chang \& Cheng. Other authors have further reduced costs by working with recycled materials, focusing on anatomy didactics but also taking environmental considerations into account (Freitas et al., 2008).

A particularly valuable skill in the training of teachers is that they may implement these teaching strategies in their own classrooms in the future, thereby better preparing future college students with regard to spatial skills and generating a virtuous cycle. This is an important aspect of this teaching and learning intervention among pre-service biology teachers because the results of Vergara (2006), for a Biology Pedagogy group, showed that they feel insecure regarding their disciplinary and didactic training; they have teachercentered classes and perceive laboratory and practical activities to be ineffective.

The latter coincides with Cofre Mardones et al. (2009), who established that less than $50 \%$ of primary school teachers conducted practical and laboratory activities up to twice a year, with these teachers using these strategies the most and agreeing that they promote motivation for science and are effective in achieving established learning objectives. Teachers who engage in laboratory activities state that they carry out experiments, demonstrations and observations, although more complex activities, such as problem solving and modeling, are excluded.

These facts show that this type of intervention among pre-service biology teachers not only significantly increases their learning of the discipline but also encourages the use of these strategies in their professional futures. They also recognize that such strategies increase their motivation and recognize them as successful interventions compared to those developed in their first two years of college (extracted from the focus group).

The focus group, an independent opinion and attitude activity during which students can express their opinions freely and anonymously, reveals valuable insights that can be used to improve learning strategies. In this case, because we are dealing with second- and third-year students who promptly referred to the anatomical models as "a successful learning experience", it is relevant to take into account that these students have passed at least fourteen different types of courses, from basic sciences (physics, chemistry, biology) to psychology and education courses.

This type of teaching strategy employing 3-D models of the knee joint is interesting due to the flexibility of the method, which means that it can be applied to other contents. In our laboratory, we already have experience in osteology, cardiac anatomy, and central nervous system anatomy, among others.

The flexibility of pedagogical intervention methods allows for them to be adapted to the individual educational needs of different schools. This has been observed with the adoption of multimedia interventions in osteology contents in different countries (Van Sint Jan et al.). Moreover, interventions requiring the learning of cross-sectional cutting can be represented (in clay) as several segments and organs (Oh et al.).

This type of teaching intervention promotes learning in the pre-service biology teacher program and is recommended for undergraduate study of the locomotor system.

\section{ACKNOWLEDGMENTS}

The authors would like to thank the Dirección de Investigación, Vice-rectoría de Investigación y Estudios Avanzados, Dirección de Desarrollo Curricular y Formativo and the Instituto de Biología of the Facultad de Ciencias of the Pontificia Universidad Católica de Valparaíso, Chile, for their constant support. They also express their gratitude to the technical illustrator Carmen Tobar, for Figure 2A, to Sergio Marshall, Ph.D., for the focus group; to Rosa Fernandez and Néstor Cortés for helpful comments and suggestions.

Grant Sponsor [Proyectos de Innovación de la Docencia]; Grant number FCS_BIO_03.2012; this work was supported in part by FONDECYT (National Fund for Scientific and Technologic Development) number 1150659.

This study was presented in part at the XXXIV Congreso Chileno de Anatomía, XV Congreso de Anatomía del Cono Sur 2013.

LIZANA, P.A.; MERINO, C.; BASSABER, A.; HENRÍQUEZ, R.; VEGA-FERNÁNDEZ, G. \& BINVIGNAT, O. Aprendizaje de la anatomía humana utilizando modelos tridimensionales a escala: Experiencia con la articulación de rodilla en profesores de biología en formación. Int. J. Morphol., 33(4):1299-1306, 2015. 
RESUMEN: El objetivo fue evaluar la eficacia de utilizar modelos de rodilla a escala real para el aprendizaje del sistema locomotor. Los participantes incluyen un total de treinta y nueve estudiantes de segundo año de un curso de anatomía humana para estudiantes de Pedagogía en Biología y Ciencias Naturales. Una semana antes de la intervención, se administró un pre-test para evaluar los conocimientos previos de los alumnos. Luego a los profesores de biología en formación se les proporcionó un modelo de yeso a escala real de los huesos de la rodilla donde se les solicitó identificar y crear su propio modelo de elementos de huesos, articulaciones y músculos. Al final de la intervención, se realizó un post-test y una encuesta de opinión, además de una comparación con otras estructuras del aparato locomotor (cuatro imágenes: articulación de la rodilla, componente muscular del miembro inferior, articulación del hombro y el hueso de la pelvis). Los puntajes de los estudiantes aumentaron significativamente en relación con el pre-test, tanto en la muestra total $(\mathrm{P}=0,000)$ y entre subgrupos divididos de acuerdo al sexo $(\mathrm{P}=0,0021$ masculino; $\mathrm{p}=0,0005 \mathrm{fe}-$ menino), así como también en comparación con otras estructuras del aparato locomotor $(\mathrm{P}<0,05)$. Por otra parte, los profesores de biología en formación mostraron altas puntuaciones en una encuesta de opinión tipo Likert, indicando que este tipo de intervenciones promueven su motivación para el curso (89,2\%), así como su aprendizaje $(97,8 \%)$ y que serían recomendable para los futuros estudiantes $(95,5 \%)$. Los resultados muestran que el uso de modelos a escala real fomenta la motivación del estudiante y mejora el aprendizaje de la anatomía humana.

PALABRAS CLAVE: Modelos anatómicos; Educación; Anatomía; Aprendizaje activo.

\section{REFERENCES}

Adúriz-Bravo, A. A 'semantic' view of scientific models for science education. Sci. Educ., 22(7):1593-611, 2013.

Bravo, H. \& Inzunza H., O. Evaluación de algunos programas computacionales en la enseñanza de anatomía y neuroanatomía de la Facultad de Medicina de la Pontificia Universidad Católica de Chile. Rev. Chil. Anat., 13(1):79-86, 1995.

Chan, L. K. \& Cheng, M. M. An analysis of the educational value of low-fidelity anatomy models as external representations. Anat. Sci. Educ., 4(5):256-63, 2011.

Cloud, B. A.; Youdas, J. W.; Hellyer, N. J. \& Krause, D. A. A functional model of the digital extensor mechanism: demonstrating biomechanics with hair bands. Anat. Sci. Educ., 3(3):144-7, 2010.

Codd, A. M. \& Choudhury, B. Virtual reality anatomy: is it comparable with traditional methods in the teaching of human forearm musculoskeletal anatomy? Anat. Sci. Educ., 4(3):119-25, 2011.

Cofre Mardones, H.; Galaz, C.; Garcia, C.; Honores, M.; Moreno, L.; Andrade, L. \& Vergara Diaz, C. Frecuencia y tipo de actividades de laboratorio que realizan profesores/as primarios en el area de las ciencias, en Santiago de Chile. Enseñanza de las Ciencias, Número Extra VIII Congreso Internacional sobre Investigación en Didáctica de las Ciencias, Barcelona, 2009. pp.3420-3. Disponible en: http:// ensciencias.uab.es/congreso09/numeroextra/art-3420-3423.pdf
Drake, R. L.; Lowrie, D. J. Jr. \& Prewitt, C. M. Survey of gross anatomy, microscopic anatomy, neuroscience, and embryology courses in medical school curricula in the United States. Anat. Rec., 269(2):118-22, 2002

Drake, R. L.; McBride, J. M.; Lachman, N. \& Pawlina, W. Medical education in the anatomical sciences: the winds of change continue to blow. Anat. Sci. Educ., 2(6):253-9, 2009.

Estevez, M. E.; Lindgren, K. A. \& Bergethon, P. R. A novel three-dimensional tool for teaching human neuroanatomy. Anat. Sci. Educ., 3(6):309-17, 2010.

Fernandez, R.; Dror, I. E. \& Smith, C. Spatial abilities of expert clinical anatomists: comparison of abilities between novices, intermediates, and experts in anatomy. Anat. Sci. Educ., 4(1):1-8, 2011.

Finn, G. M. \& McLachlan, J. C. A qualitative study of student responses to body painting. Anat. Sci. Educ., 3(1):33-8, 2010.

Freitas, L. A. M.; Barroso, H. F. D.; Rodrigues, H. G. \& Aversi-Ferreira, T. A. Construction of embryonic models with recycled material for didactic using. Biosci. J., 24:91-7, 2008.

Garg, A.; Norman, G. R.; Spero, L. \& Maheshwari, P. Do virtual computer models hinder anatomy learning? Acad. Med., 74(10 Suppl.):S87-9, 1999.

Gilbert, J. K.; Boulter, C. \& Rutherford, M. Models in explanations, Part 1: Horses for courses? Int. J. Sci. Educ., 20(1):83-97, 1998a.

Gilbert, J. K.; Boulter, C. \& Rutherford, M. Models in explanations, Part 2: Whose voice? Whose ears? Int. J. Sci. Educ., 20(2):187$203,1998 b$

Guillot, A.; Champely, S.; Batier, C.; Thiriet, P. \& Collet, C. Relationship between spatial abilities, mental rotation and functional anatomy learning. Adv. Health Sci. Educ. Theory Pract., 12(4):491-507, 2007.

Haspel, C.; Motoike, H. K. \& Lenchner, E. The implementation of clay modeling and rat dissection into the human anatomy and physiology curriculum of a large urban community college. Anat. Sci. Educ., $7(1): 38-46,2014$.

Hegarty, M.; Keehner, M.; Khooshabeh, P. \& Montello, D. R. How spatial abilities enhance, and are enhanced by, dental education. Learn. Individ. Differ., 19(1):61-70, 2009.

Hoyek, N.; Collet. C.; Rastello, O.; Fargier, P.; Thiriet, P. \& Guillot, A. Enhancement of mental rotation abilities and its effect on anatomy learning. Teach Learn Med., 21(3):201-6, 2009.

Huk, T. Who benefits from learning with 3D models? the case of spatial ability. J. Comput. Assist. Learn., 22(6):392-404, 2006.

Inzunza, O. Medical competences: the role of anatomy. Int. J. Morphol., 26(2):243-6, 2008.

Inzunza, O. \& Bravo, H. Computer animation of photographs, an actual contribution to practical learning of human anatomy. Rev. Chil. Anat., 20(2):151-7, 2002.

Inzunza, O.; D'Acuña, E. \& Bravo, H. Practical evaluation in anatomy. Performance of first year medical students in relation to different ways of asking questions. Int. J. Morphol., 21(2):131-6, 2003. 
Inzunza, O.; Vargas, A. \& Bravo, H. Anatomy and neuroanatomy the most impair in the curricular reform. Int. J. Morphol., 25(4):825-30, 2007.

Izquierdo-Aymerich, M. \& Adúriz-Bravo, A. Epistemological foundations of school science. Sci. Educ., 12(1):27-43, 2003.

Justi, R. \& Gilbert, J. Development of the notion of model. In: Behrendt, H.; Dahncke, H.; Duit, R.; Gräber, W.; Komorek, M.; Kross, A. \& Reiska, P. (Eds.). Research in Science Education - Past, Present, and Future. Londron, Springer Netherlands, 2001. pp.638-40.

Khot, Z.; Quinlan, K.; Norman, G. R. \& Wainman, B. The relative effectiveness of computer-based and traditional resources for education in anatomy. Anat. Sci. Educ., 6(4):211-5, 2013.

Latorre, R. M.; García-Sanz, M. P.; Moreno, M.; Hernández, F.; Gil, F.; López, O.; Ayala, M. D.; Ramírez, G.; Vázquez, J. M.; Arencibia, A. \& Henry, R. W. How useful is plastination in learning anatomy? J. Vet. Med. Educ., 34(2):172-6, 2007.

Levinson, A. J.; Weaver. B.; Garside, S.; McGinn, H. \& Norman, G. R. Virtual reality and brain anatomy: a randomised trial of e-learning instructional designs. Med. Educ., 41(5):495-501, 2007.

Lizana Arce, P.; Almagià Flores, A. A.; Simpson Lelievre, C.; Binvignat Gutiérrez, O.; Henríquez Flores, R. A.; Gómez Arízaga, M. P.; González Navarro, M. \& Conejeros Solar, M. L. Evaluation of teaching and learning by gifted students of an enrichment program (BETA-PUCV) of a functional neuroanatomy course. Int. J. Morphol., 28(4):1245-9, 2010.

Lufler, R. S.; Zumwalt, A. C.; Romney, C. A. \& Hoagland, T. M. Effect of visual-spatial ability on medical students' performance in a gross anatomy course. Anat. Sci. Educ., 5(1):3-9, 2012.

Masters, M. S. \& Sanders, B. Is the gender difference in mental rotation disappearing? Behav. Genet., 23(4):337-41, 1993.

McMenamin, P. G. Body painting as a tool in clinical anatomy teaching. Anat. Sci. Educ., 1(4):139-44, 2008.

Motoike, H. K.; O'Kane, R. L.; Lenchner, E. \& Haspel, C. Clay modeling as a method to learn human muscles: A community college study. Anat. Sci. Educ., 2(1):19-23, 2009.

Nersessian, N. J. Should physicists preach what they practice? Constructive modeling in doing and learning physics. Sci. Educ., 4(3):203-26, 1995.

Nersessian, N. J. Mental modeling in conceptual change. In: Vosniadou, S. (Ed.). International Handbook of Research on Conceptual Change. London, Routledge, 2008. pp.391-416.

Nolte, J. \& Angevine, J. B. The Human Brain in Photographs and Diagrams. New York, Mosby, 2007.

Oh, C. S.; Kim, J. Y.; \& Choe, Y. H. Learning of cross-sectional anatomy using clay models. Anat. Sci. Educ., 2(4):156-9, 2009.

Oliva, J. M.; Azcárate, P. \& Navarrete, A. Teaching models in the use of analogies as a resource in the science classrooms. Int. J. Sci. Educ., 29(1):45-66, 2007.

Op Den Akker, J. W.; Bohnen, A.; Oudegeest, W. J. \& Hillen, B. Giving color to a new curriculum: bodypaint as a tool in medical education. Clin. Anat., 15(5):356-62, 2002.
Preece, D.; Williams, S. B.; Lam, R. \& Weller, R. "Let's get physical": advantages of a physical model over 3D computer models and textbooks in learning imaging anatomy. Anat. Sci. Educ., 6(4):21624, 2013.

Rochford, K. Spatial learning disabilities and underachievement among university anatomy students. Med. Educ., 19(1):13-26, 1985.

Segovia Geraldo, J. \& Moreno Monje, E. Uso de yeso emparafinado en la fabricación de modelos anatómicos. An. Anat. Norm., 7:158-9, 1989.

Sugand, K.; Abrahams, P. \& Khurana, A. The anatomy of anatomy: a review for its modernization. Anat. Sci. Educ., 3(2):83-93, 2010.

Usta, A.; Onsel, V. \& Dergin, C. A new method of artificial bone modeling for medical education. Okajimas Folia Anat. Jpn., 73(2-3):143-4, 1996.

Vaccarezza, M. \& Papa, V. 3D printing: a valuable resource in human anatomy education. Anat. Sci. Int., 90(1): 64-5, 2015.

Van Sint Jan, S.; Crudele, M.; Gashegu, J.; Feipel, V.; Poulet, P.; Salvia, P.; Hilal, I.; Sholukha, V.; Louryan, S. \& Rooze, M. Development of multimedia learning modules for teaching human anatomy: application to osteology and functional anatomy. Anat. Rec. B. New Anat., 272(1):98-106, 2003.

Vergara, C. Concepciones sobre la enseñanza y el aprendizaje en profesores de biología: Coherencia entre el discurso y la práctica de aula. Tesis doctoral para optar al grado de Doctor en Ciencias de la Educación. Santiago de Chile, Pontificia Universidad Católica de Chile, 2006.

Villarroel Guerra, M. \& Medina Otazo, E. Anatomical technique to restore and/or reproduce human bone pieces difficult to obtain for research and teaching science. Int. J. Morphol., 29(2):532-6, 2011.

von Hagens, G. Impregnation of soft biological specimens with thermosetting resins and elastomers. Anat. Rec., 194(2):247-56, 1979.

Vorstenbosch, M. A.; Klaassen, T. P.; Donders, A. R.; Kooloos, J. G.; Bolhuis, S. M. \& Laan, R. F. Learning anatomy enhances spatial ability. Anat. Sci. Educ., 6(4):257-62, 2013.

Wang, H.; Northrop, C.; Burgess, B.; Liberman, M. C. \& Merchant, S. N. Three-dimensional virtual model of the human temporal bone: a standalone, downloadable teaching tool. Otol. Neurotol., 27(4):452-7, 2006.

\author{
Correspondence to: \\ Pablo A. Lizana \\ Laboratory of Morphological Sciences \\ Instituto de Biología \\ Pontificia Universidad Católica de Valparaíso \\ Avda. Universidad 330 \\ Valparaíso \\ CHILE
}

Email: pablo.lizana@ucv.cl

Received: 25-05-2015

Accepted: 23-09-2015 